\title{
Productivity and soil attributes as influenced by resource conservation technologies under rice- wheat system in Nepal
}

\author{
G Sah ${ }^{1}, \mathrm{SC} \mathrm{Shah}^{2}$, SK Sah ${ }^{2}$, RB Thapa ${ }^{2}$, A McDonald ${ }^{3}$, HS Sidhu ${ }^{4}$, RK Gupta ${ }^{5}$, and P Wall ${ }^{6}$ \\ ${ }^{1}$ Nepal Agricultural Research Council (NARC), Kathmandu, ${ }^{2}$ Institute of Agriculture and Animal \\ Science (IAAS), Rampur, ${ }^{3} \mathrm{CIMMYT}$, SARO, Nepal, ${ }^{4} \mathrm{CIMMYT}$, CSISA, New Delhi, India, \\ ${ }^{5}$ BISA, New Delhi, India, and ${ }^{6}$ CIMMYT, Mexico
}

\begin{abstract}
Rice-wheat system provides food, income, and employment to over $83 \%$ of the people and contributes to national food security in Nepal. Sustainability of the system is under threat because of increasing cultivation cost and declining soil fertility. On-farm experiments were carried out to determine the effects of tillage and crop establishment methods, crop residue management, and nitrogen levels that affect soil attributes and productivity of the rice-wheat system during 20102011 at Bara, Nepal. The treatment consisted of three tillage and crop establishment methods viz. Conventional tillage (CT), Permanent bed planting (PB), and Zero-tillage (ZT); two residue management levels viz. Residue retention and Residue removal; and three nitrogen levels viz. Zero nitrogen, farmer's dose ( 80 and $100 \mathrm{kgha}^{-1} \mathrm{~N}$ for rice and wheat, respectively), and abundant nitrogen (120 $\mathrm{kgha}^{-1} \mathrm{~N}$ for both rice and wheat crop). The experiments were laid out in strip-split plot design with three replications. The research results revealed that rice grain yield was significantly higher in the plots receiving $\mathrm{N}$ level as applied by farmers that was similar to abundant nitrogen dose. Wheat grain yield was significantly higher with zero tillage compared to permanent bed planting and conventional tillage. Significantly higher wheat grain yield was also obtained due to abundant nitrogen dose than zero dose nitrogen which was similar to farmers' dose of $\mathrm{N}$ as well. There was no significant difference in grain yield of rice and wheat due to residue retention, although, it improved soil moisture. In wheat crop, zero-till planting and increased nitrogen application conserved soil moisture, enhanced soil electrical conductivity and lowered soil temperature. It can be concluded that rice and wheat can be grown successfully with zero tillage and farmer's nitrogen dose without any yield penalty.
\end{abstract}

Key words : tillage and crop establishment, zero-tillage, permanent bed planting, crop residue

\section{Introduction}

Rice and wheat occupy 1.5 and 0.76 Million ha, respectively and are grown in succession on more than 0.56 Million ha which accounts $37 \%$ of the rice and $85 \%$ of wheat area in Nepal (Tripathi et al., 2002). Rice-Wheat-System, one of the principle cropping systems in Nepal, occupies one-fourth of the total cropped area and provides food, income and employment to $83 \%$ of the Nepalese populace. Thus, the rice-wheat system is of great importance in assuring food security and enhancing livelihood of the Nepalese people. Rice-wheat system is largely practiced on low land ecosystem where heavier soil texture, excessive soil moisture, and late rice harvest lead to higher production cost and delays in wheat planting. The traditional method of wheat establishment involves excessive tillage which is painstaking, time and energy consuming that further leads to poor plant stand and late planting (Giri, 1997; Hobbs et al., 1997; Tripathi, 2002).The turn- around 
time in rice-wheat system is 15-20 days or longer for heavy soils. With tillage, soil is opened up and made loose, and the carbon dioxide is allowed to escape into the atmosphere (Giri, 1997). Globally, agriculture and intensive tillage have caused between 30 and 50\% decrease in soil carbon since many soils were brought into cultivation over 100 years ago (Schlesinger, 1985). Plant stover is a major source of $\mathrm{C}$ input into the soil system and plays a very vital role as nourishment for the soil microbial population (Reicosky, 1997). The management of crop residues and soil organic matter is of primary importance in maintaining soil fertility and productivity (Reicosky, 1997). After rice harvest, significant crop residues (1.5-2.0 tons per hectare) are left in the field, farmers resort them to have good seedbed and employ excessive tillage resulting into high cost of cultivation, accelerated soil erosion and cause compactness of sub-soil i.e. formation of plow-pan (Regmi, 1997) that restricts the percolation of water causing temporary water-logging and restricted root penetration and growth for following crops after rice. While, rice is traditionally grown by transplanting 4-6 week old seedlings onto puddled fields which is costly and cumbersome. At the same time, nearly $20-25 \%$ of the total water $(1400-1600 \mathrm{~mm})$ used in rice culture is consumed mainly in puddling and transplanting operations. Similarly, continued puddling over decades has led to deterioration in soil physical properties through structural breakdown of soil aggregates and capillary pores and clay dispersion. Transplanting operation has an element of seasonality and is becoming a serious concern for the timely transplanting of rice and maintaining an optimally sufficient plant population. Because of the labor shortage at the peak transplanting period, farmers are forced to transplant seedlings at lesser than the optimal age (Giri, 1997). Inefficient $\mathrm{N}$ use contributes to greater use of energy resources, increased production cost, and possible pollution of water by nitrates (Sharpe et. al., 1988). In these situations, wheat seeding and direct seeded rice by zero-till drill and bed planter provide the alternative options for timely crop establishment with substantial savings in production cost and irrigation water in addition to lowered drudgery and environmental protection. Residue retention in situ conserves soil moisture, enhance soil organic carbon and N efficiency (Hobbs and Gupta 2000).

\section{Material and methods}

The on-farm experiments were conducted during Kharif (summer) and Rabi (winter) seasons, 2010/11 at Pheta VDC, Bara, Nepal. The experiment, designed under strip-split-plot design, consisted of three replications with three factors.

(a) Tillage and crop establishment (TCE) methods. (i) Conventional Tillage (CT). puddling and rice seedlings transplanting and land preparation followed by wheat seed broadcasting, (ii) Permanent Bed planting (PB). beds formation and direct seeding of rice on them and beds reshaping followed by wheat seed drilling, (iii) Zero-till planting (ZT). land preparation and direct seeding of rice on flat and wheat seed drilling on untilled soil

(b) Residue management. (i) Residue retention. wheat straw @ 4 tonha $^{-1}$ application for rice cultivation and $40 \mathrm{~cm}$ height of rice stubble left in the field for wheat (ii) Residue removal, and

(c) Nitrogen levels. (i) No N dose (for rice and wheat) (ii) Farmer's N dose @ $80 \mathrm{kgha}^{-1}$ for rice and $100 \mathrm{kgha}^{-1}$ for wheat (iii) Abundant N dose @ $120 \mathrm{kgha}^{-1}$ for both rice and wheat 
Rice variety "Sonamasuli” @ $30 \mathrm{kgha}^{-1}$ and wheat "Gautam"@120 $\mathrm{kgha}^{-1}$, foundation seeds, were planted for CT and ZT and $80 \mathrm{kgha}^{-1}$ for PB. Phosphorus $\left(\mathrm{P}_{2} \mathrm{O}_{5}\right) @ 30$ and $60 \mathrm{kgha}^{-1}$ for rice and wheat, respectively, and potassium $\left(\mathrm{K}_{2} \mathrm{O}\right) @ 30$ and $40 \mathrm{kgha}^{-1}$ for rice and wheat, respectively were applied as basal dose. Half dose of $\mathrm{N}$ was applied at transplanting/planting and remaining half in two equal split doses as top dressings, in both the crops. Pre-sowing irrigation was applied on Dec. 1, 2010 in the experimental field and wheat crop was planted on Dec. 10, 2010. Top dressings of N in wheat crop were given on 29 and 58 DAS. Sources of fertilizers were Triple Super Phosphate (TSP), Urea, and Muriate of Potash.

Conventional tillage. For rice planting, plots were plowed with a tractor drawn cultivator once (double pass), and puddling and planking were done before transplanting. Two to three seedlings were transplanted manually. For wheat, the plots were plowed twice (two passes each time) with a tractor-drawn 9-tine tiller, about $20 \mathrm{~cm}$ deep, followed by wooden planking. Seed @ $120 \mathrm{kgha}^{-1}$ and basal fertilizers were separately broadcast on the tilled soil surface followed by shallow $(7-10 \mathrm{~cm})$ seed and soil manipulation (single pass) with the tiller and wooden planking.

Zero-till planting. Before rice establishment, the field was well plowed and planked. Rice seed was drilled@30 $\mathrm{kgha}^{-1}, 3 \mathrm{~cm}$ deep, with the zero-till seed drill (inclined plate). For wheat crop establishment, without soil tilling, the seed @ $120 \mathrm{kgha}^{-1}$ was drilled with the zero-till seed-cumfertilizer drill machine, drawn with a tractor. In a pass, the drill machine planted seed in 9 rows, 20 $\mathrm{cm}$ apart and $5 \mathrm{~cm}$ deep. After seed drilling, basal fertilizers were manually broadcast followed by light planking, drawn with a tractor.

Permanent Bed planting. The beds were formed with a bed former for rice experimentation. Rice seed@30 $\mathrm{kgha}^{-1}$ was drilled in two rows on each bed. The beds were reshaped before wheat planting with the bed former attached to the Furrow Irrigated Raised Bed (FIRB) seed drill. After reshaping, the cross-section of the beds was $67.5 \mathrm{~cm}$ (bottom) X $30 \mathrm{~cm}$ (top) X $30 \mathrm{~cm}$ (depth). On the beds, two rows wheat seeds were drilled, $20 \mathrm{~cm}$ apart. Two beds were drilled in a pass of the drill and tractor. Seed drilling depth of $3 \mathrm{~cm}$ and $5 \mathrm{~cm}$, for rice and wheat, respectively, was controlled with the depth control wheels provided on the drill machine. Basal fertilizers were manually broadcast on the bed tops.

Irrigation application. The experimental plots were irrigated from a shallow tube-well through an electric motor-pump. The lifted water was conveyed to the individual plot through a $10 \mathrm{~cm}$ diameter poly-ethene pipe. The mean discharge rate of the pump was $5 \mathrm{lit} / \mathrm{sec}$. Two irrigations were applied to both the crops. For wheat crop, first irrigation was applied at the crown root initiation stage (22 DAS) and second on 53 DAS. While, irrigating in the furrows of the beds, water was applied below $5 \mathrm{~cm}$ of bed-top, in both the crops.

Rainfall recording. At the experimental site, a rain-gauge was installed. During the crop cycles, rainfall data were recorded daily at 8 a.m. During rice season, total rainfall $513.8 \mathrm{~mm}$; and during wheat $25 \mathrm{~mm}$ were received in two spells (69 and 108 DAS).

Herbicide application. For rice crop, pre-emergence herbicide, Pendemethalin was sprayed @ 3.3 litha $^{-1}$, two days after seed drilling. A mixture of 2, 4-D and Isoproturone @ 900 gha $^{-1}$ each, was sprayed on 34 DAS, with a knap-sack sprayer. 
Soil moisture content, pore-water electrical conductivity, and soil temperature. Soil moisture (\%), pore-water conductivity $\left(\mathrm{mS} \cdot \mathrm{m}^{-1}\right)$, and soil temperature $\left({ }^{0} \mathrm{C}\right)$, during the wheat crop cycle, were recorded with the WET Sensor (HH-2), on 6, 29, 40, 48, 58, and 68 DAS. The WET Sensor, records the above three parameters in the root zone directly in $5 \mathrm{sec}$. For that, the sensor probe with three rods, was gently inserted into the top soil surface. Pressing the button on the WET Sensor, with thumb, displayed soil moisture (\%) and was recorded, again the button was pressed, and the displayed value of soil electrical conductivity was recorded. This way pressing the button again, the displayed value of soil temperature $\left({ }^{0} \mathrm{C}\right)$ was recorded. Thus, 5 samples were randomly recorded, in each plot and the mean values of the above parameters were computed.

Crop sampling. At crop maturity, crop samples $\left(10 \mathrm{~m}^{2}\right.$ for ZT and CT, and $13.5 \mathrm{~m}^{2}$ for PB) for both the crops, were harvested. Wheat crop samples were harvested on 127 DAS. Samples were weighed, threshed, and cleaned. Grain moisture of individual plot was recorded. Thus, rice grain yields (at $14 \% \mathrm{~m}$. c.) and wheat grain yields (at $12 \% \mathrm{~m}$. c.) were computed. Straw yields were calculated. Data were analyzed by Genstat 5 .

\section{Results and discussions}

Grain yield. The grain yields of rice were not significant with tillage and crop establishment methods and residue management but differed significantly with nitrogen doses. The plots receiving farmer's N-dose $\left(80 \mathrm{kgha}^{-1}\right)$ and abundant $\mathrm{N}$-dose $\left(120 \mathrm{kgha}^{-1}\right)$ produced statistically at par grain yields, but, significantly higher than zero-nitrogen application. The wheat grain yields were significantly influenced by tillage and crop establishment methods and nitrogen levels, but, not by residue management (Table 1). Zero-till wheat produced significantly higher grain yield (2777 $\mathrm{kgha}^{-}$ $\left.{ }^{1}\right)$ than permanent bed planting $\left(2438 \mathrm{kgha}^{-1}\right)$ and conventional tillage $\left(2499 \mathrm{kgha}^{-1}\right)$. The yields of permanent bed planting and conventional tillage were at par with each other. The application of abundant nitrogen $\left(120 \mathrm{kgha}^{-1}\right)$ and farmer's N-dose $\left(80 \mathrm{kgha}^{-1}\right)$ produced statistically similar wheat grain yields, but, significantly higher than zero-N application. The higher wheat grain yield was due to higher soil moisture conservation at reproductive stage of the crop (Table 2), higher pore-water electrical conductivity (Table 3), and lower soil and canopy temperature (Tables $4 \& 5$ ) with zerotillage than conventional tillage. Application of residues had positive effect on yield advantages, though small, in rice, but, adverse in wheat. It is obvious that the effect of residues was not stable in second crop cycle. Conversion from conventional tillage to reduced till systems with residue retention may require several crop cycles before potential advantages/disadvantages begin to become apparent (Phillips and Phillips, 1984; and Sayre, 2000). 
Table 1. Rice and wheat yields influenced by tillage methods, residue management, and nitrogen levels at Pheta, Bara, Nepal, $2010 / 11$

\begin{tabular}{|c|c|c|c|c|}
\hline \multirow[t]{2}{*}{ Treatment } & \multicolumn{2}{|c|}{ Grain yield $\left(\mathrm{kgha}^{-1}\right)$} & \multicolumn{2}{|c|}{ Straw yield $\left(\mathrm{kgha}^{-1}\right)$} \\
\hline & Rice & Wheat & Rice & Wheat \\
\hline \multicolumn{5}{|l|}{ Tillage methods. } \\
\hline Conventional tillage $\quad(\mathrm{CT})$ & 5190 & 2499 & 4808 & 2737 \\
\hline Permanent bed planting (BP) & 5117 & 2438 & 4745 & 2299 \\
\hline Zero tillage $\quad(\mathrm{ZT})$ & 5213 & 2777 & 4847 & 2846 \\
\hline $\operatorname{LSD}_{(0.05)}$ & (NS) & $216.2(* *)$ & (NS) & $429.5(*)$ \\
\hline C. V. $(\%)$ & 10.1 & 12.4 & 33.5 & 24.1 \\
\hline \multicolumn{5}{|l|}{ Residue management. } \\
\hline Residue retention $(4$ tons $/ \mathrm{ha} \& 40 \mathrm{~cm}$ & 5238 & 2494 & 2803 & 2054 \\
\hline stubble) & 5109 & 2648 & 6797 & 3201 \\
\hline Zero residue & (NS) & (NS) & $890(* *)$ & $350.7(* *)$ \\
\hline $\operatorname{LSD}_{(0.05)}$ & 10.1 & 2.4 & 33.5 & 24.1 \\
\hline C. V. $(\%)$ & & & & \\
\hline \multicolumn{5}{|l|}{ Nitrogen levels. } \\
\hline Zero nitrogen & 4547 & 1239 & 3916 & 1306 \\
\hline Farmers' nitrogen dose & 5508 & 3176 & 5194 & 3282 \\
\hline Abundant nitrogen dose & 5455 & 3298 & 5291 & 3292 \\
\hline $\operatorname{LSD}_{(0.05)}$ & $352.6(*)$ & $216.2(* *)$ & $1090.1(*)$ & $429.5(* *)$ \\
\hline C. V. $(\%)$ & 10.1 & 12.4 & 33.5 & 24.1 \\
\hline
\end{tabular}

Note. NS, Not significant, ${ }^{*}$ F-value significant at $5 \%$ level of significance, $* *$ and $1 \%$ level of significance

The other reasons for higher grain yield with ZT compared to $\mathrm{CT}$ might be most probably due to higher tiller numbers per unit area, higher thousand grain weight, lower weed pressure, and lower foliar blight. The reasons for lower grain yield with residue retention could be most probably due to partial utilization of residual/applied amendments by rice stubbles and soil microbial activities in early stage and light shading effect by rice stubbles ( $40 \mathrm{~cm}$ length).

Harvested straw yield. The harvested rice straw yields with tillage and crop establishment methods were not significant, while, they differed significantly with residues retention and nitrogen levels. Residues removal produced significantly higher harvested straw yield of rice $\left(6797 \mathrm{kgha}^{-1}\right)$ compared to residue retention $\left(2803 \mathrm{kgha}^{-1}\right)$. Abundant $\mathrm{N}$-dose $\left(120 \mathrm{kgha}^{-1}\right)$ and farmer's N-doze $\left(80 \mathrm{kgha}^{-1}\right)$ showed statistically similar harvested rice straw yields, but, significantly higher than zero-N application. The wheat harvested straw yields were significantly influenced by tillage and crop establishment methods, residue management, and nitrogen levels. The wheat harvested straw yields with abundant nitrogen $\left(120 \mathrm{kgha}^{-1}\right)$ and farmer's nitrogen dose $\left(100 \mathrm{kgha}^{-1}\right)$ were at par statistically, but, were significantly higher than zero-N application. The harvested wheat straw yields were 2846, 2737, and $2299 \mathrm{kgha}^{-1}$ with zero tillage, conventional tillage, and permanent bed planting, respectively (Table 1). The harvested straw yields of rice and wheat were lower with residues retention than residues removal as $40 \mathrm{~cm}$ stubbles were left in first case.

Soil moisture content. During wheat season, the effect of TCE methods on root-zone moisture varied highly significantly to not significantly (Table 2). Soil moisture in tilled soil was found lower 
because of higher and faster evaporation loss. Soil moisture was lower in CT $(19.05 \%)$ compared to PB (24.79\%) and ZT (23.15\%) on 6 DAS. But, on 29 and 48 DAS, soil moisture was higher in CT compared to PB and ZT because of higher irrigation water application $\left(900 \mathrm{~m}^{3} \mathrm{ha}{ }^{-1}\right)$ in CT compared to ZT $\left(520 \mathrm{~m}^{3} \mathrm{ha}^{-1}\right)$ and PB $\left(370.8 \mathrm{~m}^{3} \mathrm{ha}^{-1}\right)$ at first irrigation on 22 DAS. But, in all three TCE methods, soil moistures were found in descending order as time elapsed. Second irrigation was applied on 52 DAS. Likewise, soil moistures were lower in CT compared to PB and ZT on 58 and 68 DAS. Residues retention showed higher soil moisture compared to residue removal on each observation date. Thus, residues retention lowered evaporation loss from the ground surface showing higher soil moisture.

Table 2. Soil moisture during wheat season as influenced by tillage methods, residue management, and nitrogen levels at Pheta, Bara, Nepal, 2010/11

\begin{tabular}{|c|c|c|c|c|c|c|}
\hline \multirow[t]{2}{*}{ Treatment } & \multicolumn{6}{|c|}{ Soil moisture (\%) Days after seeding } \\
\hline & 6 & 29 & 40 & 48 & 58 & 68 \\
\hline \multicolumn{7}{|l|}{ Tillage methods. } \\
\hline Conventional tillage $\quad(\mathrm{CT})$ & 19.1 & 32.6 & 27.0 & 24.1 & 27.9 & 18.2 \\
\hline Permanent bed planting (BP) & 24.8 & 31.4 & 27.2 & 22.5 & 29.6 & 20.5 \\
\hline Zero tillage $\quad(\mathrm{ZT})$ & 23.2 & 30.5 & 27.0 & 23.8 & 28.5 & 20.2 \\
\hline $\operatorname{LSD}_{(0.05)}$ & $1.92 * *$ & $0.99 * *$ & NS & NS & $\mathrm{NS}$ & $1.94 *$ \\
\hline C. V. $(\%)$ & 12.7 & 4.7 & 6.9 & 9.7 & 9.5 & 14.6 \\
\hline \multicolumn{7}{|l|}{ Residue management. } \\
\hline \multicolumn{7}{|l|}{ Residue retention ( 4 tons $/$ ha $\&$} \\
\hline Zero residue & 22.1 & 31.3 & 25.7 & 21.7 & 28.2 & 17.7 \\
\hline $\operatorname{LSD}_{(0.05)}$ & NS & NS & $1.03 * *$ & $1.26 * *$ & NS & $1.59 * *$ \\
\hline C. V. $(\%)$ & 12.7 & 4.7 & 6.9 & 9.7 & 9.5 & 14.6 \\
\hline \multicolumn{7}{|l|}{ Nitrogen levels. } \\
\hline Zero nitrogen & 22.5 & 31.4 & 26.6 & 22.8 & 28.6 & 20.0 \\
\hline Farmers' nitrogen dose & 21.9 & 31.3 & 26.7 & 23.5 & 28.5 & 19.2 \\
\hline Abundant nitrogen dose & 22.6 & 31.8 & 26.8 & 24.0 & 28.9 & 19.7 \\
\hline $\operatorname{LSD}_{(0.05)}$ & NS & NS & NS & NS & NS & NS \\
\hline C. V. $(\%)$ & 12.7 & 4.7 & 6.9 & 9.7 & 9.5 & 14.6 \\
\hline
\end{tabular}

Pore-water electrical conductivity. On all observation dates, pore-water electrical conductivity $\left(\mathrm{mS} . \mathrm{m}^{-1}\right)$ was the highest for PB followed by ZT and the lowest with CT (Table 3). For all TCE methods, soil electrical conductivities were in ascending order up to $40 \mathrm{DAS}$, after that they were in descending order up to 58 DAS, then again rose on 68 DAS, because precipitation of $17 \mathrm{~mm}$ was received on 68 DAS. The soil electrical conductivities varied highly significantly to not significant on the six observation dates for the tillage methods. The soil electrical conductivity was the lowest with CT (of $68.1 \mathrm{mS}^{-1} \mathrm{~m}^{-1}$ ) on 6 DAS, while, it was the highest with PB (of $173.7 \mathrm{mS} . \mathrm{m}^{-1}$ ) on 40 DAS. It is obvious that pore-water electrical conductivities were higher, in small magnitude, with residue retention compared to residue removal, on all observation dates. Also, pore-water electrical conductivities enhanced with increased $\mathrm{N}$ applications at all the observation dates, but significantly, at $29,40,48$, and 68 DAS. 
Table 3. Pore-water electrical conductivity during wheat season as influenced by tillage methods, residue management, and nitrogen levels at Pheta, Bara, Nepal, 2010/11

\begin{tabular}{|c|c|c|c|c|c|c|}
\hline \multirow[t]{2}{*}{ Treatment } & \multicolumn{6}{|c|}{ Pore-water electrical conductivity $\left(\mathrm{mS} . \mathrm{m}^{-1}\right)$ Days after sowing } \\
\hline & 6 & 29 & 40 & 48 & 58 & 68 \\
\hline \multicolumn{7}{|l|}{ Tillage methods. } \\
\hline Conventional tillage & 68.1 & 93.9 & 122.2 & 128.2 & 91.9 & 102.2 \\
\hline Permanent bed planting (BP) & 116.4 & 168.4 & 173.7 & 147.9 & 126.3 & 117.9 \\
\hline Zero tillage $\quad(\mathrm{ZT})$ & 92.1 & 117.8 & 148.9 & 141.1 & 101.5 & 117.5 \\
\hline $\operatorname{LSD}_{(0.05)}$ & $12.6 * *$ & $17.1 * *$ & $15.9 * *$ & NS & $14.4 * *$ & NS \\
\hline C. V. $(\%)$ & 20.1 & 19.9 & 15.8 & 18.8 & 19.9 & 24.4 \\
\hline \multicolumn{7}{|l|}{ Residue management. } \\
\hline $\begin{array}{l}\text { Residue retention ( } 4 \text { tons } / \text { ha } \& \\
40 \mathrm{~cm} \text { stubble) }\end{array}$ & 93.7 & 126.9 & 150.8 & 144.1 & 107.8 & 104.7 \\
\hline Zero residue & 90.7 & 126.6 & 145.8 & 134.1 & 105.4 & 120.4 \\
\hline $\operatorname{LSD}_{(0.05)}$ & NS & NS & NS & NS & NS & $15.2 *$ \\
\hline C. V. $(\%)$ & 20.1 & 19.9 & 15.8 & 18.8 & 19.9 & 24.4 \\
\hline \multicolumn{7}{|l|}{ Nitrogen levels. } \\
\hline Zero nitrogen & 89.4 & 100.3 & 115.8 & 110.3 & 88.7 & 96.9 \\
\hline Farmers' nitrogen dose & 89.6 & 132.6 & 155.9 & 146.4 & 106.7 & 111.6 \\
\hline Abundant nitrogen dose & 97.7 & 147.2 & 173.2 & 160.5 & 124.3 & 129.1 \\
\hline $\operatorname{LSD}_{(0.05)}$ & NS & $17.1 * *$ & $15.9 * *$ & 17.68 & NS & $18.6 * *$ \\
\hline C. V. $(\%$ & 20.1 & 19.9 & 15.8 & $\begin{array}{c}* * \\
18.4\end{array}$ & 19.9 & 24.4 \\
\hline
\end{tabular}

Note. NS, Not significant, ${ }^{*}$ F-value significant at $5 \%$ level of significance, ${ }^{* *}$ and $1 \%$ level of significance

Soil temperature. Soil temperature varied highly significantly, significantly, and not significantly for TCE methods on the observation dates (Table 4). It was the highest with CT followed by PB and the lowest with ZT on 48, and 58 DAS. For the TCE methods, soil temperature increased from 29 DAS up to 58 DAS as first irrigation was applied on 22 DAS. Soil temperatures for TCE methods lowered on 29 and 68 DAS compared to previous observation dates because of first irrigation at 22 DAS and rainfall on 68 DAS . At all the observation dates, soil temperatures were lower with residue retention compared to residue removal. It is obvious that residue retention keeps soil cooler. 
Table 4. Soil temperature during wheat season as influenced by tillage methods, residue management, and nitrogen levels at Pheta, Bara, Nepal, 2010/11

\begin{tabular}{|c|c|c|c|c|c|c|}
\hline \multirow[t]{2}{*}{ Treatment } & \multicolumn{6}{|c|}{ Soil temperature $\left({ }^{0} \mathrm{C}\right)$ Days after sowing } \\
\hline & 6 & 29 & 40 & 48 & 58 & 68 \\
\hline \multicolumn{7}{|l|}{ Tillage methods. } \\
\hline Conventional tillage & 20.5 & 14.8 & 15.0 & 20.2 & 24.0 & 18.2 \\
\hline Permanent bed planting (BP) & 20.5 & 14.5 & 18.5 & 20.0 & 23.6 & 18.3 \\
\hline Zero tillage $\quad(\mathrm{ZT})$ & 20.1 & 15.0 & 17.5 & 19.9 & 23.0 & 18.3 \\
\hline $\operatorname{LSD}_{(0.05)}$ & NS & $0.11 * *$ & $0.45^{* *}$ & NS & $0.78 *$ & NS \\
\hline C. V. $(\%)$ & 3.1 & 1.1 & 3.6 & 4.2 & 4.9 & 0.9 \\
\hline \multicolumn{7}{|l|}{ Residue management. } \\
\hline \multicolumn{7}{|l|}{ Residue retention ( 4 tons/ha \& } \\
\hline Zero residue & 20.7 & 14.8 & 18.9 & 20.8 & 24.5 & 18.3 \\
\hline $\operatorname{LSD}_{(0.05)}$ & $0.35 * *$ & NS & $0.37 * *$ & $0.46 * *$ & $0.63 * *$ & NS \\
\hline C. V. $(\%)$ & 3.1 & 1.1 & 3.6 & 4.2 & 4.9 & 0.9 \\
\hline \multicolumn{7}{|l|}{ Nitrogen levels. } \\
\hline Zero nitrogen & 20.3 & 14.8 & 18.4 & 20.4 & 24.3 & 18.3 \\
\hline Farmers' nitrogen doze & 20.4 & 14.8 & 18.3 & 19.9 & 23.2 & 18.2 \\
\hline Abundant nitrogen doze & 20.4 & 14.8 & 18.3 & 19.7 & 23.1 & 18.3 \\
\hline $\operatorname{LSD}_{(0.05)}$ & NS & NS & NS & $0.6 *$ & $0.8 * *$ & NS \\
\hline C. V. $(\%)$ & 3.1 & 1.1 & 3.6 & 4.2 & 4.9 & 0.9 \\
\hline
\end{tabular}

Note. NS, Not significant, ${ }^{*}$ F-value significant at $5 \%$ level of significance, ${ }^{* *}$ and $1 \%$ level of significance

\section{Reference}

Augustin, LO, KD Sayre, and CA Francis. 2000. Wheat Nitrogen Use Efficiency in a Bed Planting System in Northwest Mexico. Agron. J. 92(2).303-308.

Bhatta, MR. 2008. Food security. Contribution and vision for sustainable wheat production in Nepal. Third SAS-Nepal Convention on Agril. Res. for Enhancing Livelihood of Nepalese People.

Giri, GS. 1997. Effect of Rice and Wheat Establishment Techniques on Wheat Grain Yields. pp. 6668. In. Hobbs and Rajbhandari (ed.). Proceeding of the Rice-Wheat Research, End-ofProject Workshop, 1-3 October, 1997, Kathmandu, Nepal. Mexico, D.F..NARCCIMMYT-RWCIGP.

Gupta, RK. 2003. Production Constraints of the Rice-Wheat System. Addressing Resource Conservation Issues in Rice-Wheat System of South Asia (A Resource Book). pp 32-33.

Hobbs, PR, LW Harrington, C Adhikary, GS Giri, SR Upadhyay, and B Adhikary. 1996. Wheat and Rice in Nepal Tarai. Farm Resources and Production Practices in Rupandehi District. Mexico, D.F.. NARC and CIMMYT.

Hobbs, PR, and RK Gupta. 2000. Sustainable resource management in intensively cultivated irrigated rice-wheat cropping systems of the Indo-Gangetic Plains of South Asia. Strategies and options. P. 157. In A.K. Singh(ed.). Proc. Int. Conf. Managing Res. For Sustainable 
Agric. Prod. In the $21^{\text {st }}$ Century. New Delhi, India. 14-18 Feb. 2000. Indian Soc., Soil Sci., New Delhi, India.

Hobbs, PR. 2001.Tillage and Crop Establishment in South Asian Rice-Wheat System. Present Practices and Future Options. Pp.1-22.. In.. Kataki, P.K. (ed). The Rice-Wheat System of South Asia. Efficient Production Management. Food Products Press, New York, UDA.

Hobbs, PR. 2003. Alternative to Puddling and Manual Transplanting. Addressing Resource Conservation Issues in Rice-Wheat Systems of South Asia, RWCIGP. pp129-135.

Hobbs, PR and Gupta, RK. 2004. Problems and challenges of no-till farming for the rice wheat systems of the Indo-Gangetic Plains in South Asia. In sustainable agriculture and the rice wheat system, 101-119. Columbus, OH, and New York, NY. Ohio state university and Marcel Dekker.

Regmi, AP. 1997. Long Term Soil Fertility Experiment in the Rice-Wheat System, Nepal. pp. 6366. In. Hobbs and Rajbhandari (ed.). Proceedings of the Rice-Wheat Research, End-ofProject Workshop, 1-3 October, 1997, Kathmandu, Nepal. Mexico, D.F..NARCCIMMYT-RWCIGP.

Reicosky, DC. 1997.Technologies for improved soil carbon management and environmental quality. Pg. 127-136. In. Incorporating Climate Change Into corporate Business Strategies. Intl. Climate Change Conf. Proc. June 12-13, 1997. Baltimore, MD.

Reicosky, DC. 1997. Tillage-induced carbon-dioxide emission from soil. Nutrient Cycling in Agroecosystems 49. 273-285.

Sayre, KD. 2000. Effect of Tillage, Crop Residue Retention and Nitrogen Management on the Performance of Bed-Planted, Furrow Irrigated Spring Wheat in Northwest Mexico. $15^{\text {th }}$ Conference of the International Soil Tillage Research Organization; July 2-7, 2000; Fort Worth, Texas, USA.

Tripathi, J, D Bhandari, Scott Justice, NK Shakya, TP Kharel and R Sishodia. 2002. Resource Conservation Technologies for Wheat Production in Rice-Wheat System, Proceedings of Wheat Research Papers presented at $25^{\text {th }}$ National Winter Crops Workshop. 